\title{
Investigation of Academic Staff's Self-Efficacy Using the Educational Internet
}

\author{
Okan Gültekin ${ }^{1}$, Sabriye Erkaplan ${ }^{1}$, Hatice Uzun ${ }^{1} \&$ Esra Güney ${ }^{1}$ \\ ${ }^{1}$ Faculty of Sports Sciences, Uludağ University, Bursa, Turkey \\ Correspondence: Okan Gültekin, Physical Education \& Sport department, Faculty of Sports Sciences, Uludağ \\ University, Bursa, Turkey. E-mail: otekin@uludag.edu.tr
}

Received: April 26, 2020

Accepted: May 29, 2020 Online Published: June 3, 2020

doi:10.5539/hes.v10n3p26

URL: https://doi.org/10.5539/hes.v10n3p26

\begin{abstract}
The Covid-19 pandemic has had negative effects throughout the whole world, including education systems. To overcome this negativity, all educational institutions have turned to internet-based education. However, the educator's self-efficacy is of more importance in this system. This study aimed to reveal the connection between the University academic staff's genders, ages, titles (doctorate/non-doctorate), and work year characteristics and their self-efficacy beliefs about their educational Internet usage. The sample consists of $100[51 \%(\mathrm{n}=51)$ female and 49\% ( $\mathrm{n}=49)$ male] academic staff, who were selected according to convenience sampling in the Faculty of Education and Faculty of Sport Sciences at Uludag University. In this study, the "Educational Internet Usage Self-Efficacy Beliefs" scale, developed by Şahin (2009), was used to collect data. Descriptive statistics refer to number and percentage for qualitative variables; quantitative variables are summarized using mean, median, standard deviation, and minimum and maximum statistics. Univariate analyses used binary group comparisons with the Student's t-test and relationships between numerical variables and Spearman correlation coefficients. Multiple regression analysis was used, in conjunction with the backward method, for the multivariate linear regression method. Analysis results alpha (Type I error) value was evaluated at the level of 0.05 significance. The mean level of self-efficacy belief of academic staff is 109,42 . Since the highest score that can be obtained from the scale is 140 , the relationships between scale score and age and duration of service variables are significant according to the univariate analysis, while differences in gender and $\mathrm{PhD}$ and non- $\mathrm{PhD}$ groups are not significant. When multiple linear regression analysis is applied with the backward stepwise method, age and academic title variables are significant in the model. Additionally, the mean scale scores of $\mathrm{PhD}$ academicians are higher than others.
\end{abstract}

Keywords: educational internet, self-efficacy beliefs, academic staff

\section{Introduction}

Internet use has been spreading rapidly since 1995, radically changing the production, storage, publication of, and access to, information. The Internet has caused significant changes and innovations in education. The Internet has eliminated the time, space, and distance constraints in education, and access to various educational contents has become much easier. Also, Internet use has grown rapidly because of social media. According to some research, the Internet is a place where people meet with friends, work, and compare their needs in areas of expertise, entertainment, and education (Şahin, 2009; Toplu and Gökçearslan, 2012; Balc1, Arsal Gölcü, and Eray Öcalan, 2013; Yoldaş and Argın, 2015).

Various education studies have been conducted (Vekiri, 2008; Albion, 2001; Adalıer, 2013; and Günlü, 2017) to examine Internet usage among university students. These studies explored students' attitudes toward educational usage of the Internet following websites for education, sharing educational information with friends online, classifying their needs for Internet usage, and general and educational use of the Internet. With rapid progress in mobile communication technology, the methods of communication, collaboration, and access to information have increased among university students and faculty members. Mobile communication technologies commonly used in education today include smart phones, laptops, tablets, and personal digital assistants. Mobile communication technologies offer teachers and students a more flexible approach (Pan and Akay, 2016).

Teachers' ability to use the Internet effectively and improve themselves has become an obligation. Using the Internet in education can offer numerous learning opportunities given the individual characteristics of the 
students, such as plain text, videos, images, animations, simulations, etc. It is an ideal resource to bring all teaching materials into the classroom environment. Moreover, the Internet's use as an information source, the communication feature also contributes to education. Students can communicate directly with their peers, teachers, and specialists via the Internet. With these aspects, the Internet is a technology that deeply affects all sectors after computers (Özbişirici, 2006).

Use of the Internet in teaching not only affects teacher and student roles, but also changes the quality of education. Integrating technological innovations means that other elements of the education system are affected. It is important for teachers to know what they do, why they do it, and how they do it. Therefore, teachers need to integrate various technologies with learning theories. Successful integration of technology with educational philosophy may require changes in classroom management and curriculum objectives. Arslan (2017) noted that the time and effort spent implementing these tools would result in little educational progress unless it is combined with pedagogy, curriculum, assessment, and other simultaneous innovations in school organizations.

Media and technology development have been accompanied by a paradigm shift in school education. Rather than learning from only teacher's lectures, many students are becoming accustomed to exploring new knowledge and expanding their learning and interests through media. Traditional school education methods face criticism that learning content should reflect current societal trends. Therefore, teacher-training programs should be improved to support the changing needs of a new generation. Binkley et al. (2012) defined twenty-first century skills as follows: 1) creativity and innovation; 2) critical thinking, problem-solving, and decision making; 3) learning to learn and metacognition; 4) communication; 5) collaboration; 6) information literacy; 7) Information and Communication Technology literacy; 8) citizenship; 9) life and career; and 10) personal and social responsibility. Griffin et al. (2012) also confirmed those learning skills are required in the twenty-first century; however, they believed that the skills the new generation requires do not differ entirely from previous ones. Because important learning abilities are based on twentieth century technology, new technologies will be merged with a new learning environment based on the previous school environment (citied by Cheyeon, 2019)

The Internet has changed the roles of teachers in education, and the teacher has become the person who guides the student to reach information rather than a conveyor of information. Thus, contemporary teachers must be adequately equipped in terms of accessing current and accurate information, as well as using information, educational technologies, and the Internet in education (Polatcan, 2015; Yoldaş and Argın, 2015).

However, using technology in universities does not go beyond the routine use of some office programs and electronic mail (Surry, 2000). The use of technology for educational purposes and the preference for mobile learning environments require the individuals at the relevant education level to accept and adopt these technologies. Studies on this subject show that the technology acceptance model explains the use and adoption of mobile learning and mobile technologies for educational purposes at the university level (Park, 2009; Y.S. Wang, Wu, and H.Y. Wang, 2009; Park, Nam, and Cha, 2012).

Studies show that teachers' self-efficacy has positive effects on students' attitudes and behaviors toward school (Tschannen-Moran and Hoy, 1998), their success (Ross, 1992), their motivation (Midgley, Feldlaufer, and Eccles, 1989), and students' own self-efficacy (Anderson, Greene, and Loewen, 1988; Cited by Gürol and Akt1, 2010). In this sense, one of the significant features that teachers should have is Internet self-efficacy. Tsai and Tsai (2003), describe Internet self-efficacy as individuals' perceptions and beliefs about Internet usage skills. Teachers' with high self-efficacy while using it for educational aims make us think that the learning process can be conducted more efficiently and productively (Sırkaya, 2015).

Bandura (1997) introduced the theory of self-efficacy, which states that self-efficacy expectations are based on four major sources of information: (1) performance accomplishment (also called in active mastery experience), (2) vicarious experience, (3) verbal persuasion, and (4) physiological states. These four principles are considered the core elements of self-efficacy development in general, including in the learning context. Performance accomplishment, the first source of information, is the most influential as it is based on learners' previous successful experience. Repeated successes develop strong efficacy expectations that lead to reducing the negative affect of failure. As a result, Bandura states improvements in behavioral functioning transfer not only to similar situations but also to activities that are substantially different from those on which the treatment was focused (Bandura, 1997).

Use of the Internet, which has a very wide range of uses, has accelerated with modern educational applications, especially the increasing popularity of Internet-based learning environments, which is a branch of computer-based education. However, being able to use Internet-based learning environments efficiently is related to self-efficacy in Internet use. In other words, individuals with high Internet self-efficacy beliefs can be much 
more successful than individuals with weak Internet self-efficacy beliefs in performing their tasks in the Internet-based learning environment (Durmuş, 2014).

Internet usage self-efficacy beliefs appear effective for academic staff's proper and effective use of the Internet to guide their students and become informed about educational technologies. Investigating the factors affecting these beliefs will make a positive contribution to the literature. For this reason, the study sought answers to the following questions to determine the educational Internet self-efficacy beliefs of academic staff and the factors affecting them.

\subsection{The Aim of Study}

The aim of the study is to analyze academic staff's Internet self-efficacy beliefs in terms of certain variables. With this aim, we sought responses to the following questions.

1- Do lecturers' educational use of Internet self-efficacy beliefs differ according to gender?

2- Do lecturers' educational use of Internet self-efficacy beliefs differ according to work years?

3- Do lecturers' educational use of Internet self-efficacy beliefs differ according to PhD- and non-PhD?

\section{Method}

\subsection{Research Design}

The descriptive research was in accordance with the correlational research model. This type of research aims to evaluate the degree and the variation between two or more variables (Kabir, 2016).

\subsection{The Universe and Sample of the Study}

The study population consists of the academic staff at Uludag University. The sample consists of 100 [51\% ( $\mathrm{n}=$ 51) female and $49 \%(n=49)$ male] academic staff who were selected according to convenience sampling in the Faculty of Education and Faculty of Sport Sciences at Uludag University. Title distributions are as follows; Professor 8, Associate Professor 30, Instructor (PhD) 22, Instructor (non-PhD) 24, Research Assistant 16. For statistical calculation purposes, academic titles were evaluated as those who do and do not have a $\mathrm{PhD}$ because they are numerically insufficient. The research data were collected in November and December in the 2019-2020 fall semester.

\subsection{Research Instruments}

Demographic Information Form: This 8-item form was prepared by the researcher to collect data about teachers' genders, doctorate degrees or non-doctorate degrees, and working years.

Educational Internet Usage Self-Efficacy Beliefs Scale: The scale for Educational Internet Usage Self-Efficacy Beliefs Scale has 28 items, developed by İsmail Şahin (2009), to identify participants' educational Internet usage self-efficacy beliefs. The survey items are written as sentences. The survey items are answered by means of a Likert type scale with five response choices, including " $1=$ not qualified," " $2=$ somewhat qualified," " 3 = qualified," " 4 = quite qualified," and " 5 = completely qualified." The minimum and maximum scores that could be received from the scale were between 28 and 140, respectively. The Cronbach's alpha reliability coefficient of the scale was calculated to be. 96 .

\section{Results}

Descriptive statistics number and percentage for qualitative variables: Quantitative variables are summarized using mean, median, standard deviation, and minimum and maximum statistics. For univariate analyses, binary group comparisons with Student's t-test and relationships between numerical variables and Spearman correlation coefficients were used. Multiple regression analysis was used in conjunction with the backward method for the multivariate linear regression method. Analysis results alpha (Type I error) value was evaluated at the level of 0.05 significance.

Table 1 . The mean level of self-efficacy beliefs of academic staff

\begin{tabular}{llllll}
\hline & $\overline{\mathbf{x}}$ & Med. & S & Min & Max. \\
\hline Overall Mean & 109,42 & 115,50 & 26,044 & 28 & 140 \\
\hline
\end{tabular}

According to Table 1, the mean level of self-efficacy belief of academic staff is 109.42. Since the highest score that can be obtained from the scale is 140, academic staff who participated in the study considered themselves sufficient in terms of educational Internet usage. 
Table 2. The Descriptive Statistics of the sampling grop in terms of same demographic variable

\begin{tabular}{llllll}
\hline & $\overline{\mathbf{x}}$ & Med & S & Min & Max \\
\hline Age & 44.49 & 43.00 & 9.336 & 25 & 65 \\
Working year & 19.98 & 20.00 & 9.511 & 1 & 42 \\
Overall mean & 109.42 & 115.50 & 26.044 & 28 & 140 \\
\hline
\end{tabular}

\section{Univariate analysis}

Table 3. Independent t-test scores of Educational Internet Usage Self-Efficacy Beliefs Scale

\begin{tabular}{lccccc}
\hline & $\mathbf{n}$ & Med & S & $\mathbf{t}$ & $\mathbf{p}$ \\
\hline Female & 51 & 110.24 & 23.70 & \multirow{2}{*}{0.318} & 0.751 \\
Male & 49 & 108.57 & 28.50 & & \\
\hline
\end{tabular}

Table 3 shows the difference between genders in terms of scale scores is not statistically significant $(t=0.318 ; \mathrm{p}$ $=0.751$ ).

Table 4. Independent t-test scores of doctorate and non-doctorate academic staff

\begin{tabular}{lccccc}
\hline & n & Med & S & t & p \\
\hline PhD & 60 & 112.45 & 24.93 & 1.432 & 0.155 \\
Non-PhD & 40 & 104.88 & 27.32 & & \\
\hline
\end{tabular}

Table 4 shows, in terms of scale scores, the difference between people with and without doctorates is not statistically significant. $(\mathrm{t}=1.432 ; \mathrm{p}=0.155)$.

Table 5. Age and working years in terms of scale scores

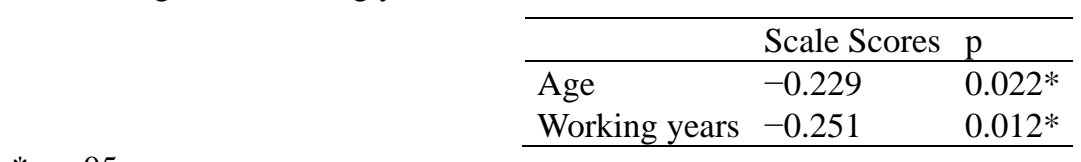

$* \mathrm{p}<.05$.

Table 5 shows the difference between age $(\mathrm{p}=0.022)$ and working years $(\mathrm{p}=0.012)$ in terms of scale scores is statistically significant.

There is a weak negative relationship between age and scale scores (scale scores decrease as age increases) $(\mathrm{rs}=$ $-0.292 ; p=0.022$ ). Figure 1 indicated that the scale scores of people under the age of 35 are, on average, higher than the older people. There is a weak negative relationship between the study year and the scale scores (scale points decrease as the year of study increases) ( $r s=-0.251 ; \mathrm{p}=0.012$ ).

Figure 2 shows that the scale scores of people working fewer than 5-6 years are higher than the scale scores of the people who have more years of working. 


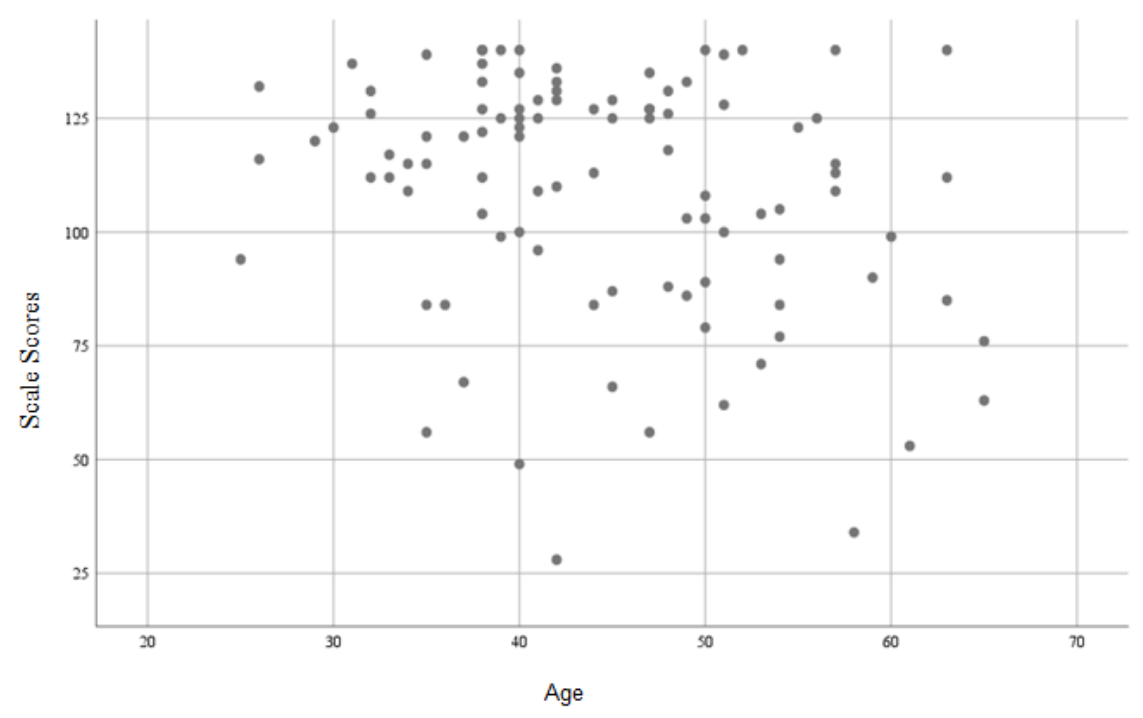

Figure 1. Scatter plot for age and scale scores

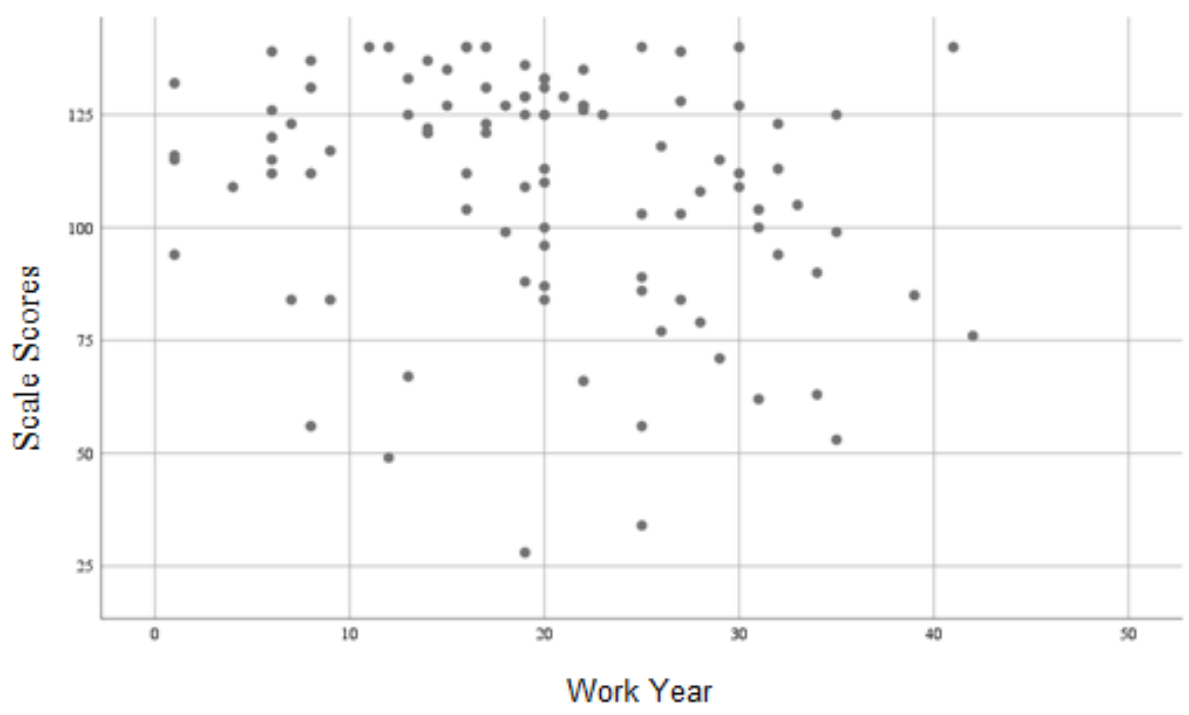

Figure 2. Scatter plot for work year and scale scores

\section{Multivariate analysis}

According to the results of univariate analyses, the relationships between scale scores and age and working years variables were significant, while the differences in gender and doctoral groups were not significant. However, calculating the effect of any variable on the scale score, when the effect of other variables is controlled, will make more accurate estimates. For this reason, multiple linear regression analysis, in which the scale score dependent variable, age, gender, doctorate, and working year variables are independent variables, was applied with the backward method.

In the first step, multiple linear connection problems emerged between the age and working year variables (vif $=$ 9.617). Since the $\mathrm{p}$ value was 0.776 , it was removed from the model.

In the second step, since the $\mathrm{p}$ value of the gender variable is 0.579 , it was removed from the model.

Finally, age and doctorate variables were found significant in the model (in order of, $p=0.003$ and $p=0.042$ ). It explains $9 \%$ of the variance in model scale scores $(\mathrm{F}=5,909 ; \mathrm{p}=0,004)$. According to the model results, each age increase causes a decrease of 0.844 points on the scale score. The scale scores of doctorate academicians are 10,655 points higher than others. 
Table 6. Multiple linear regression analysis results for scale score

\begin{tabular}{llllll}
\hline & B & SH & Beta & t & P \\
\hline Constant & 129.912 & 13.525 & & 9.605 & $<0.001$ \\
Age & -0.844 & 0.273 & -0.302 & -3.096 & 0.003 \\
PhD & 10.655 & 5.167 & 0.201 & 2.062 & 0.042 \\
\hline
\end{tabular}

R-squared $=0.109$ Adjusted R-square $=0.090 \mathrm{SE}=24.841 \mathrm{~F}(2.97)=5.909 \mathrm{p}=0.004$

Variables included in the first model: Age, Gender, $\mathrm{PhD}$, working year.

\section{Discussion}

For quality education, academic staff's confidence in their ability to use the Internet is crucial. It affects their motivation, attitude, and performance in Internet-based educational environments. Besides, the Internet is a dynamic technology; hence, periodically examining teachers' educational internet usage self-efficacy beliefs using an instrument with items that reflect recent developments in Internet technology is very important. This is especially true because of Covid-19 pandemic, when teachers must overcome the lack of face-to-face education with Internet-based education opportunities.

Although some studies (Mustafa, 2013) found that male teaching staff has higher Internet usage frequency than female teaching staff in general, the frequency of use should not be confused with educational internet usage self-efficacy beliefs. In our study, it was determined that Internet use self-efficacy beliefs did not differ significantly between genders. $(\mathrm{p}=0.751)$.

This result could suggest that the traditional gender gap, in which the males were more confident in their ability to use the Internet than females, may be narrowing or disappearing (Tsai and Lin, 2004; Tsai and Tsai, 2010). Similar results were also reported in many recent studies performed on teachers and students (Cited by Kahraman, 2018). The narrowing or disappearing gender gap in Internet self-efficacy was not a surprising finding. In recent years, the Internet has become an indispensable part of education and daily life. It is often used by both female and male teachers for different educational and daily activities, such as searching on the Internet using search engines, sharing documents with students using file-sharing tools, collaborating with colleagues using collaboration tools, and communicating with students and peers using online communication tools and e-mail. In our study, the determination that the participants found self-efficacy beliefs sufficient for using the Internet for educational purposes also supports the explanation mentioned above. $(\overline{\mathrm{x}}=109.42)$.

In our research findings, the difference between titles $(\mathrm{PhD} / \mathrm{non}-\mathrm{PhD})$ in terms of scale scores is not statistically significant. Although we achieved different results in our study, we found use of the Internet for teaching purposes varied significantly according to academic titles. Teaching staff use the Internet for teaching purposes more often than professors, associate professors, and assistant professors (Mustafa, 2013). The reason why this result does not correspond with our research may be attributed to the separation of groups as doctorate and non-doctorate since it will not be statistically significant. In our study, the statistical significance according to the scale score of age and working year supports this result.

Furthermore, the Internet usage of the instructors for teaching purposes does not change according to the departments in which they work. A study conducted by Demir (2001) on Internet usage purposes of faculty members concluded that it does not change according to the departments in which they work.

According to some studies, education Internet self-efficacy beliefs differed in favor of teachers aged 30 and under (Yenilmez et al., 2011; Tekinarslan, 2008). According to these results, young teachers follow technology faster and use the Internet and Internet applications more often when preparing a lesson. Compared to teachers aged 51 and over, teachers aged 30 and under use the Internet more bravely in their educational activities. With the rapid change in technology, young teachers give up traditional teaching methods and prefer computer-assisted teaching methods, whereas teachers aged 51 and over are more timid about using the Internet for information purposes; this weakens self-efficacy beliefs in using the Internet for educational purposes (Balay, 2015). These data coincide with our research results between the ages of academics and their Internet self-efficacy beliefs.

As emphasized in the previous articles, teachers' Internet self-efficacy is an issue that should be addressed in a serious way. It is very important that teachers are able to use the Internet effectively for their professional development and their students' learning outcomes. In other words, teachers frequently use the Internet for educational purposes, such as accessing content, resources, and materials for professional development and 
teaching, working with colleagues collaboratively, and sharing teaching materials with students. High Internet self-efficacy is considered one of the most critical factors for the effective use of the Internet.

The Internet is a technology that changes at an extraordinary pace, and teachers who are confident in using it will be more likely to adopt technological innovations to support teaching and learning than those who are not. It is not scientific to continue with an understanding that academically advanced and older academicians leave their shortcomings in the use of educational Internet and learn when they need it. Likewise, prior experience in using the Internet is seen as the most effective way of strengthening individuals' Internet self-efficacy. Therefore, it is very important to organize in-service training programs that will help teachers improve their confidence and enthusiasm regarding both basic and advanced use of the Internet and encourage them to participate in these programs. The literature (citied by Kahraman, 2018) has evidence suggesting that properly designed training can be a highly effective way to enhance individuals' Internet self-efficacy significantly (Kim, Glassman, Bartholomew, and Hur, 2013; Ren, 2000; Torkzadeh, Chang, and Demirhan, 2006; Torkzadeh and Van Dyke, 2002).

However, the relevant literature ( $\mathrm{Wu}$ and Wang, 2015) and the current study have revealed that teachers generally tended to have lower confidence in using the Internet for advanced, rather than basic, purposes. Therefore, one of the most important goals of training programs should be to increase teachers' advanced Internet self-efficacy by providing them with experiences that reach beyond their daily Internet-based activities.

As a result, age and duration of service did not affect the effective use of the Internet; seeing the Internet as valuable and meaningful is about developing the skills necessary to use it in some way. The research data were obtained in November and December 2019, when the Covid-19 pandemic has not yet begun worldwide. For this reason, a study on academics/teachers' educational Internet self-efficacy after the pandemic can reveal whether they have developed these skills and self-efficacy because they find the Internet valuable and meaningful.

\section{References}

Adlier, A. (2013). Prospective teachers' educational internet usage self-efficacy beliefs. Mediterranean Journal of Educational Research, 14a, 918-925.

Albion, R. P. (2001). Some factors in the development of self-efficacy beliefs for computer use among teacher education students. Journal of Technology and Teacher Education: Society for Information Technology \& Teacher Education, Waynesville, NC, USA.

Arslan, A., \& Şendurur, P. (2017) Investigation of changes in factors affecting the technology integration in education. Journal of Mehmet Akif Ersoy Universtiy Education Faculty, 43, 25-50. https://doi.org/10.21764/efd.21927

Balc1, Ş., Arsal, G. A., \& Eray, Ö. M. (2013). Internet usage patterns among university students. Selçuk İletişim, 7(4), 5-22.

Bandura, A. (1994). Self-efficacy. In V. S. Ramachaudran (Ed.), Encyclopedia of Human Behavior (pp. 71-81). Academic Press, New York.

Balay, R., Kayak, A., \& Çevil, N. M. (2014). Teachers' attitudes towards internet and their level of self-efficiency beliefs toward use of internet in education. Karadeniz Uluslararası Bilimsel Dergi, 1(23), 16-23. https://doi.org/10.17498/kdeniz.01935

Ha, C., \& Lee, S. Y. (2019). Elementary teachers' beliefs and perspectives related to smart learning in South Korea. Smart Learning Environments, 6(1), 2-15. https://doi.org/10.1186/s40561-019-0082-5

Durmuş, A., \& Başparmak, U. (2014). Investigation of the relation between teacher candidates internet self-efficiency belief and their problematic intended use. Ahi Evran University, Journal of Kirşehir Education Faculty, 15(3), 49-67.

Günlü, A., \& Ceyhan, A. A. (2017). Investigating adolescents' behaviors on the internet and problematic internet usage. Addicta: The Turkish Journal on Addictions, 4(1), 75-117. https://doi.org/10.15805/addicta.2017.4.1.0016

Gürol, A., \& Akt1, S. (2010). The relationship between pre-service teachers' self-efficacy and their internet self-efficacy. Procedia-Social and Behavioral Sciences, 2(2), 3252-3257. https://doi.org/10.1016/j.sbspro.2010.03.497

Kahraman, S., \& Yilmaz, Z. A. (2018). In-service teachers' internet self-efficacy: a re-examination of gender differences. Turkish Online Journal of Distance Education-TOJDE, 19(2), 72-85. 
https://doi.org/10.17718/tojde.415675

Kabir, M. S. S. (2016). Basic guidelines for research: an introductory approach for all disciplines. Edition: First Chapter: 6 Publisher: Book Zone Publication, Chittagong-4203, Bangladesh.

Midgley, C., Feldlaufer, H., \& Eccles, J. S. (1989). Change in teacher efficacy and student self and task-related beliefs in mathematics during the transition to junior high school. Journal of Educational Psychology, 81(2), 247-258. http://doi.org./10.1037/0022-0663.81.2.247

Mustafa, M. Q., \& Şahin, S. (2013). Internet usage of the instructors for educational purpose. Educational Technology Theory and Practice, 3(1), 1-12.

Özbişirci, Ş. (2006). Internet uses of teachers. Unpublished Master's Thesis: Hacettepe University, Ankara.

Park, S. Y. (2009). An analysis of the technology acceptance model in understanding university students' behavioral intention to use e-learning. Educational Technology and Society, 12(3), 150-162.

Park, S. Y., Nam, M. W., \& Cha, S. B. (2012). University students' behavioral intention to use mobile learning: evaluating the technology acceptance model. British Journal of Educational Technology, 43(4), 592-605. https://doi.org/10.1111/j.1467-8535.2011.01229.x

Polatcan, F. (2015). Attitudes and opinions of prospective Turkish teachers regarding computer use. Mustafa Kemal Üniversitesi Sosyal Bilimler Enstitüsü Dergisi, 12(32), 388-400.

Şahin, İ. (2009). Validity and reliability of educational internet use self-efficacy beliefs. Journal of Selcuk University Institute of Social Sciences, 21, 461-471.

Sırkaya, M., Başparmak, U., \& Baltacı, Ö. (2015). Analysis of teacher candidates' educational internet self-efficacy beliefs in terms of various variables. Procedia-Social and Behavioral Sciences, 174, 3094-3101. https://doi.org/10.1016/j.sbspro.2015.01.1046

Tekinarslan, E. (2008). Faculty of education students' attitudes toward internet and implications for onlıne learning. Journal of Abant Izzet Baysal University, Education Faculty, 8(1), 67-82.

Toplu, M., \& Gökçearslan, Ş. (2012). Development of e-learning and reflections of the internet on the process of education: a case study at Gazi University. Türk Kütüphaneciliği, 26(3), 501-535.

Tsai, C. C., \& Lin, C. C. (2004). Taiwanese adolescents' perceptions and attitudes regarding the Internet: exploring gender differences. Adolescence, 39(156), 725-734.

Tsai, M. J., \& Tsai, C. C. (2003). Information searching strategies in web-based science learning: the role of internet self-efficacy. Innovations in Education and Teaching International, 40, 43-50. https://doi.org/10.1080/1355800032000038822

Tschannen-Moran, M., \& Hoy, W. (1998). Trust in schools: a conceptual and empirical analysis. Journal of Educational Administration, 36(4), 334-352. https://doi.org/10.1108/09578239810211518

Vekiri, I., \& Chronaki, A. (2008). Gender issues in technology use: perceived social support, computer self-efficacy and value beliefs, and computer use beyond scholl. Journal of Computers \& Education, 51(3), 1392-1404. http://doi.org/10.106/j.compedu.2008.01.003

Wang, Y. S., Wu, M. C., \& Wang, H. Y. (2009). Investigating the determinants and age and gender differences in the acceptance of mobile learning. British Journal of Educational Technology, 40(1), 92-118. https://doi.org/10.1111/j.1467-8535.2007.00809.x

Wu, Y. T., \& Wang, L.-J. (2015). The exploration of elementary school teachers' Internet self-efficacy and information commitments: a study in Taiwan. Educational Technology and Society, 18(1), 211-222.

Yenilmez, K., Turgut, M., Anapa, P., \& Ersoy, M. (2011). Preservice elementary mathematics teachers' self-efficacy beliefs in educational internet use. E-Journal of New World Sciences Academy, 7(1).

Yoldaş, C., \& Argın, F. S. (2015). The analysis of belief of self-efficiency of educational internet usage of students who study at the faculty of education. Journal of Education and Teaching, 4(1), 276-283.

\section{Copyrights}

Copyright for this article is retained by the author(s), with first publication rights granted to the journal.

This is an open-access article distributed under the terms and conditions of the Creative Commons Attribution license (http://creativecommons.org/licenses/by/4.0/). 